\title{
Mechanisms of the Morphological Plasticity Induced by Phytohormones and the Environment in Plants
}

\author{
Gaojie Li ${ }^{1,2} \mathbb{D}$, Shiqi Hu ${ }^{1,2} \mathbb{D}$, Xuyao Zhao ${ }^{1,2}$, Sunjeet Kumar ${ }^{1,2}$, Yixian Li ${ }^{1,2}$, Jingjing Yang $1,2, * \mathbb{D}$ \\ and Hongwei Hou 1,2,*(D)
}

1 The State Key Laboratory of Freshwater Ecology and Biotechnology, The Key Laboratory of Aquatic Biodiversity and Conservation of Chinese Academy of Sciences, Institute of Hydrobiology, Chinese Academy of Sciences, Wuhan 430072, China; ligaojie@ihb.ac.cn (G.L.); hushiqi@ihb.ac.cn (S.H.); zhaoxuyao@ihb.ac.cn (X.Z.); sunjeet@ihb.ac.cn (S.K.); liyixian@ihb.ac.cn (Y.L.)

2 College of Modern Agricultural Sciences, University of Chinese Academy of Sciences, Beijing 100049, China

* Correspondence: yangjj@ihb.ac.cn (J.Y.); houhw@ihb.ac.cn (H.H.); Tel.: +86-27-68788691 (H.H.)

check for updates

Citation: Li, G.; Hu, S.; Zhao, X.; Kumar, S.; Li, Y.; Yang, J.; Hou, H Mechanisms of the Morphological Plasticity Induced by Phytohormones and the Environment in Plants. Int. J. Mol. Sci. 2021, 22, 765. https:// doi.org/10.3390/ijms22020765

Received: 15 December 2020 Accepted: 12 January 2021 Published: 14 January 2021

Publisher's Note: MDPI stays neutral with regard to jurisdictional clai$\mathrm{ms}$ in published maps and institutional affiliations.

Copyright: $(\odot 2021$ by the authors. Licensee MDPI, Basel, Switzerland. This article is an open access article distributed under the terms and conditions of the Creative Commons Attribution (CC BY) license (https:// creativecommons.org/licenses/by/ $4.0 /)$.

\begin{abstract}
Plants adapt to environmental changes by regulating their development and growth. As an important interface between plants and their environment, leaf morphogenesis varies between species, populations, or even shows plasticity within individuals. Leaf growth is dependent on many environmental factors, such as light, temperature, and submergence. Phytohormones play key functions in leaf development and can act as molecular regulatory elements in response to environmental signals. In this review, we discuss the current knowledge on the effects of different environmental factors and phytohormone pathways on morphological plasticity and intend to summarize the advances in leaf development. In addition, we detail the molecular mechanisms of heterophylly, the representative of leaf plasticity, providing novel insights into phytohormones and the environmental adaptation in plants.
\end{abstract}

Keywords: environment; leaf; morphological plasticity; phytohormones; molecular mechanism

\section{Introduction}

Leaves are key interfaces between plants and their surrounding environment, functioning to capture sunlight, synthesize photosynthate, exchange gasses, sense ambient changes, and regulate their growth under heterogeneous conditions [1-3]. In part because of their sessile lifestyle, plants possess efficient systems of morphological plasticity and acclimation to environmental changes. The diversity of leaf shape, vein pattern, stomata, and other parameters not only vary among plants that belong to different species (Figure 1A) but also within a single plant [4-6] (Figure 1B). It is well known that the same genotype is capable of developing different phenotypes, which is regarded as the coordination of phenotype, development, and environment $[7,8]$. For example, heteroblasty was described as the changes in leaf shape during growth development [9], while anisophylly is coupled with asymmetry and leaf phyllotaxis [10]. Some species have even evolved the ability to develop significantly different leaf types under heterogeneous conditions, a phenomenon called heterophylly [11-13]. Furthermore, heteroblasty indicates the juvenile-to-adult transition marked by morphological changes, and it emphasizes the developmental stage-related plasticity [14]. However, heterophylly is an extreme morphological plasticity, which is induced by environmental conditions $[12,13]$. This morphological plasticity provides good models for studying leaf development. However, the mechanisms related to how plants sense environmental changes and develop final leaf forms is still not elucidated.

Given the rapid developments of plant functional genomics, many genes controlling leaf development have been studied, and the regulatory networks underlying these morphological processes have been well characterized [15]. Despite the fact that leaf development is related to genotype, the final shape is adjusted by environmental conditions, such 
as light, temperature, atmospheric carbon dioxide $\left(\mathrm{CO}_{2}\right)$ concentrations, and submergence, to adapt to environmental variables $[1,16]$. The modulation of phytohormone signaling and distributions is a very effective strategy for quick environmental responses. Phytohormones are long-range molecular signals and have key functions in regulating plant growth and leaf development [11,17-26]. Thus, environmentally induced changes in hormone concentration, distribution, and/or sensitivity can promote coordinated developmental responses [27-31].

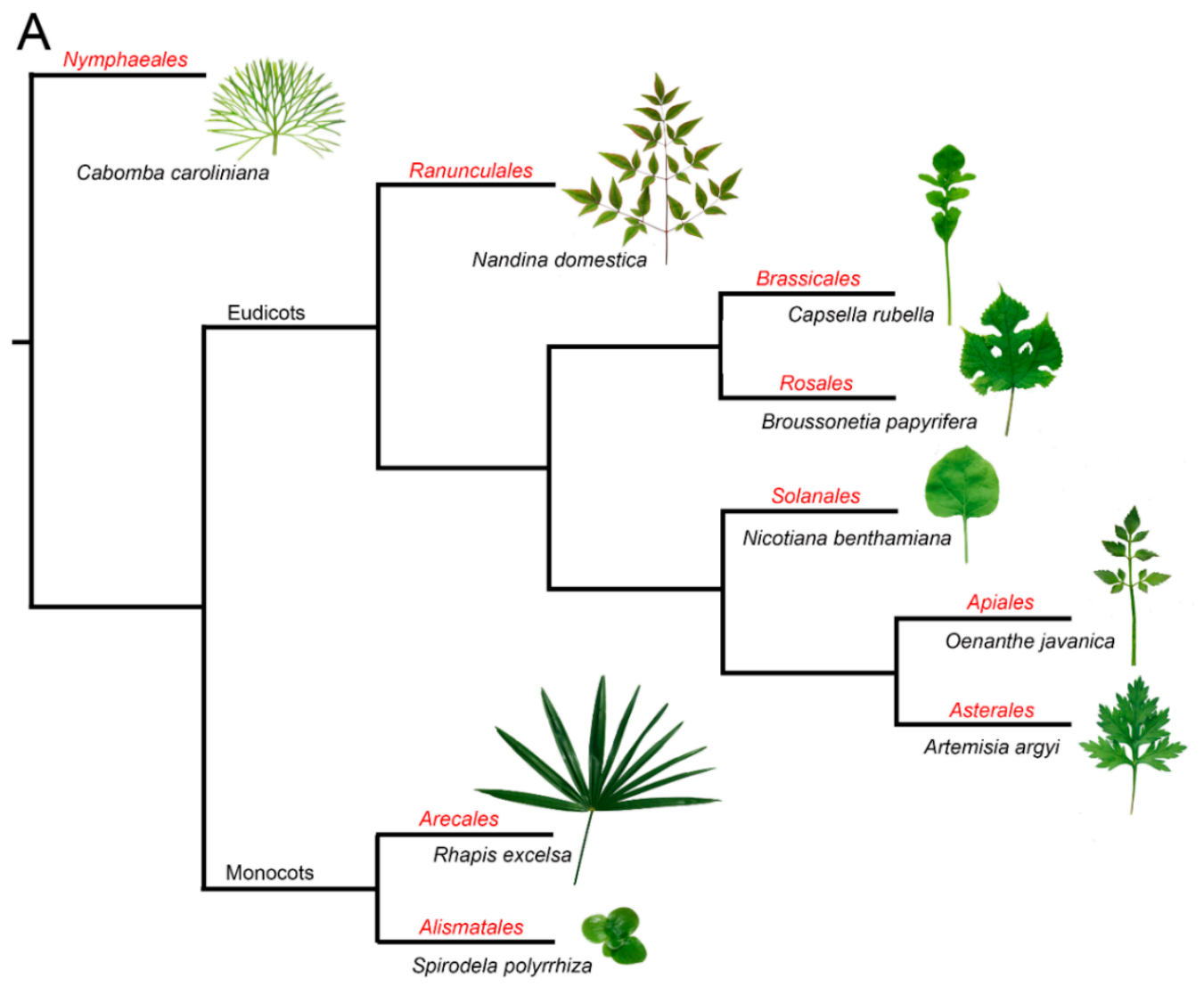

B

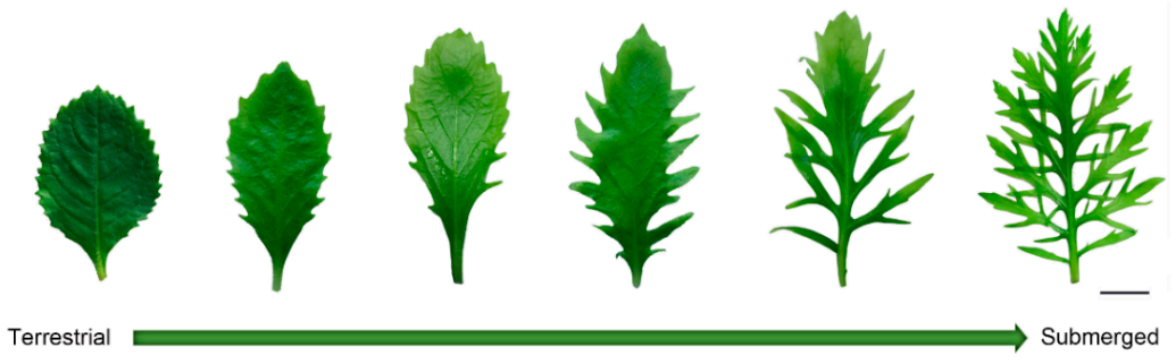

Figure 1. The phylogeny and typical leaf shape among plant species. (A) The phylogeny and typical leaf shape among species from different orders. Red text indicates the order name. (B) Leaves from a heterophyllous plant (Hygrophila difformis) shifted from terrestrial to submerged conditions. Successive leaves are in phyllotactic order. Bar $=1 \mathrm{~cm}$. All photos were taken by the camera (Canon EOS80D, Japan) and plant materials were collected from the Key Laboratory of Aquatic Biodiversity and Conservation of Chinese Academy of Sciences (Institute of Hydrobiology, Chinese Academy of Sciences). The phylogenetic tree was based on the online software "Phylomatic" (http://phylodiversity.net/phylomatic/).

Here, we detailed the current knowledge on the molecular mechanisms underlying morphological plasticity regarding the environment, including environmental sensing, phytohormone signals, and leaf development in plants. Learning how plants use adaptive 
strategies in nature will help us to gain novel insights into plant science and further improve crops associated with a changing climate.

\section{Environmental Sensing and Adaptation to Light and Temperature}

Photosynthesis efficiency depends on the light capture of leaves. As a result, the balance of maximizing light capture and minimizing the harmful impact of high light is a coordinated developmental response. For example, plants prefer to develop broad leaves to maximize light capture, but if the sunlight is too harsh it may lead to overheating and cause harm to the plants [32,33]. In contrast, leaf development also responds to shade (a reduction in the red $(660 \mathrm{~nm})$ to far-red $(730 \mathrm{~nm}), \mathrm{R} / \mathrm{FR})$, which is called shade avoidance syndrome (SAS), showing petioles elongation, leaf upward bending, and leaf area decreasing $[34,35]$ (Figure 2A). The upward movement of the leaves allows the plant to elevate the position of the foliage in order to maximize light capture $[34,36]$. Other aspects are also affected by light, such as leaf complexity, stomata density, and leaf thickness, which increased in the high light conditions [16,37-39]. In Rorippa aquatica (Brassicaceae), leaf complexity is dramatically increased in high light conditions [40]. In some other species, such as Nuphar lutea (Nymphaeaceae), Rumex palustris (Polygonaceae), and Hygrophila difformis (Acanthaceae), light change even induced the rearrangement of chloroplasts and altered the photosynthetic biochemistry to adapt the plant to aquatic conditions [41-43]. The photoperiod also significantly regulates leaf form. For example, short daylength induced submerged leaves, while long daylength induced terrestrial leaves of P. palustris and Ranunculus aquatilis (Ranunculaceae) [44,45].

Increasing surrounding temperature affects numerous developmental traits among plants, and the morphological changes that occur in plants in response to temperature changes are called thermomorphogenesis [46-48]. In order to adapt to high temperatures, plants developed elongated hypocotyls and petioles, as well as a decrease in leaf thickness and an increasing stomatal density $[47,49,50]$. These morphological responses are believed to cool plants and reduce the damage caused by sunlight through the upward bending of leaves $[46,51,52]$. Leaf dissection has for a long-time been thought to correlate with ambient temperature [5]. For example, plants growing in cold climates tend to develop serrated or deep-lobed leaves, while plants growing in warm conditions display shallow-lobed leaves [53-57]. To some degree, leaf dissection was used as an indicator for predicting paleoclimate $[5,58]$. The change in temperature of a single leaf of $R$. aquatica affects the epidermal cell size in developing leaves, and hence the morphology of the whole plant is affected [1,59]. In Ludwigia arcuata (Onagraceae), low temperature induced the elongation of epidermal cells and thus lead to the aquatic leaf form [60]. It was recently verified that pectin and cortical microtubules drive morphogenesis in plant epidermal cells $[61,62]$, but how these epidermal changes are regulated by temperature is still unknown.

It was verified that auxin signal functions to connect temperature sensing with growth responses in hypocotyls [63,64]. In Arabidopsis thaliana, temperature changes can be sensed by the inactivation of photoreceptors such as phytochrome $B$ (phyB), whose function in thermoregulation operates via the PHYTOCHROME-INTERACTING FACTOR 4 (PIF4) for high temperature-induced hypocotyl elongation $[65,66]$. High temperature-activated PIF4 directly upregulates the expression of auxin biosynthesis genes (e.g., YUCCA8, TAA1, and $C Y B 79 B 2$ ), and as a result, the accumulated auxin induces hypocotyl elongation and leaf hyponasty $[67,68]$. High temperature also induced PIF4 expression by inactivating EARLY FLOWERING 3 (ELF3) that directly represses PIF4. In high temperature conditions, ELF3 binding to the PIF4 promoter is decreased, and thus PIF4 was activated for thermomorphogenesis $[69,70]$. Auxin could theoretically induce elongation growth; however, it was recently reported that the phytohormone brassinosteroid (BR) activates elongation growth downstream of auxin to act in themomorphogenesis [71,72]. 

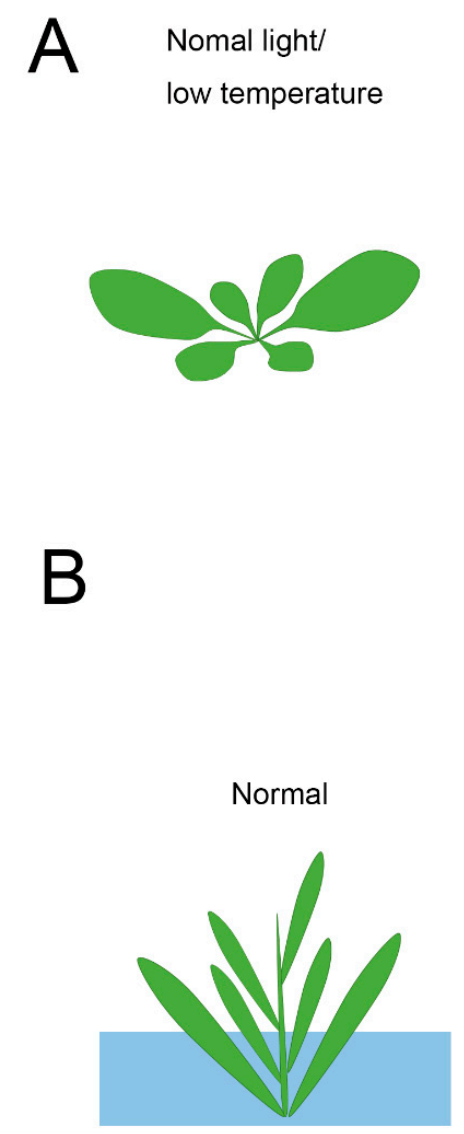

Shade/

high temperature
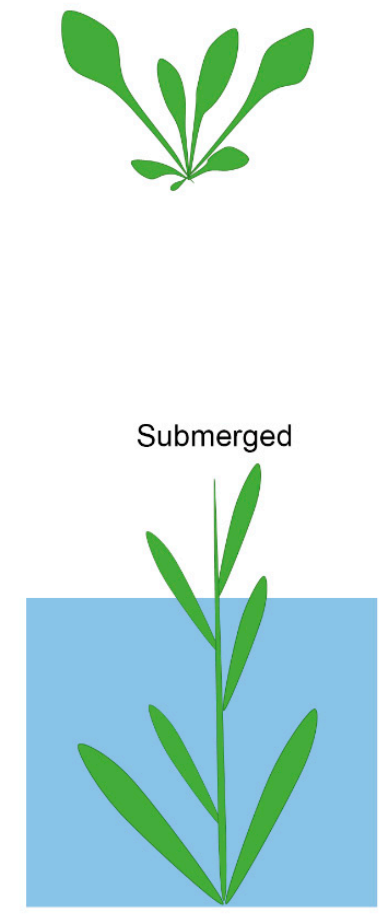
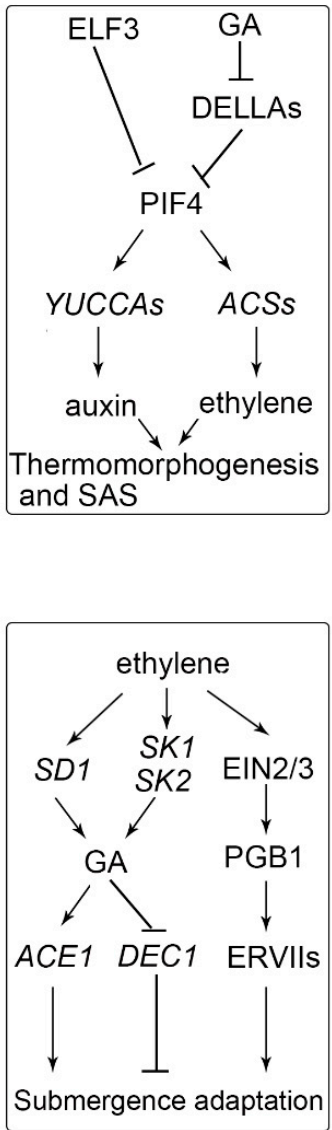

Figure 2. Example of plant developmental responses to environmental changes. (A) Both shaded light and an increase in temperature induce the elongation of the petiole, a reduction of leaf area, and an upward movement of the leaves. ELF3 directly represses PIF4, and this repression was released in shade/high temperature conditions. PIF4 activates auxin synthesis by upregulating YUCCAs and activating ethylene synthesis by upregulating ACSs for thermomorphogenesis and shade avoidance syndrome (SAS). Shade/high temperature also induces high levels of gibberellic acid (GA) and the degradation of DELLAs, which therefore release PIF4 for binding to target promoters. (B) Deepwater rice activates stem elongation growth depending on the water level. Submerged conditions accumulate high ethylene and activate SD1 for GA synthesis. GA promotes stem elongation through the activation of ACE1 and repression of DEC1. Ethylene also induced EIN2/EIN3 signaling and thus enhanced PGB1 to improve ERFVII stability for flooding survival.

Temperature and light signals are integrated into the PIF and the relevant genetic network, which controls auxin biosynthesis $[67,73]$. Photomorphogenesis and shade avoidance responses, including stem/hypocotyl elongation are mediated by PIF4 [74]. The stability of the PIF4 protein is regulated by light, and it is dephosphorylated and stable in the dark, while it is rapidly phosphorylated by phyB-mediated signaling and degradation upon red light irradiation [74]. Interestingly, although phyB and PIF4 antagonistically regulate photomorphogenesis and shade avoidance responses, they cooperatively promote stomatal development in response to high light [39]. Shade also induces the expression of gibberellic acid (GA) biosynthetic enzymes and leads to an accumulation of GA, which then promotes the degradation of DELLAs. It was found that DELLA directly interacts with PIF4 and prevents it from binding to target promoters $[75,76]$. Besides, the ethylene response also shows short hypocotyls, short roots, and an exaggerated apical hook [77]. PIF4 also promotes ethylene biosynthesis by activating the expression of ethylene biosynthesis genes (e.g., $A C S 2,6,8$, and 9) and enhances ethylene signaling by activating the transcription factor ETHYLENE INSENSITIVE 3 (EIN3) [78,79].

Light and temperature are the most critical environmental factors for plant growth, and even a slight change can lead to disasters of plants [80,81]. We mentioned above that PIF4 may be a key element that functions in the light/temperature-dependent morphological 
plasticity and the crosstalk of phytohormones such as auxin, ethylene, and GA. Future studies based on these gene pathways and phytohormones will not only reveal novel mechanisms on the light and temperature response but will also have implications on crop improvement through use of these plastic strategies.

\section{Environmental Sensing and Adaptation to Submergence}

Under flooding or submerged conditions, plants find it difficult to obtain enough $\mathrm{O}_{2}$ for respiration. Terrestrial plants, such as A. thaliana and Solanum lycopersicum (tomato), which are intolerant to flooding, find that submerged conditions induce their leaves to turn pale and suppresses their plant growth [73,82]. Deepwater rice survive periodic flooding and consequent oxygen deficiency by activating an internode growth of stems to keep above the water [83] (Figure 2B). In other species such as $R$. palustris, elongated leaves and decreased thickness helps the plant to obtain a relatively increased gas exchange under submerged conditions [41]. In some aquatic, dimorphic types of plants, their submerged leaves are always thin, narrow, or dissected and contain fewer stomata, while aerial leaves are thick, broad, and entire, and have more stomata [12,40,84,85]. Although narrow or dissected leaves are less efficient at absorbing sunlight than those with wider blades, they can better withstand the destructive force of water flow and more efficiently incorporate $\mathrm{CO}_{2}$ and mineral nutrients than entire leaves [86-88].

ABA and ethylene are key regulators of drought and submerge response, separately. ABA was regarded as a stress hormone, which accumulates rapidly in response to drought/dehydration stress and plays a crucial role in stomatal closure, root growth, and the production of protective metabolites [20,89]. ABA levels in unstressed plants are low, but accumulated highly under reduced water potentials by the activation of key synthesis genes 9-cis-epoxycarotenoid dioxygenases (NCEDs) [90]. Upon perception of ABA, the ABA receptor pyrabactin resistance 1 (PYR1)-like protein PYL, regulatory components of the ABA receptor (RCAR) proteins, inhibit the activity of clade A protein phosphatase type $2 \mathrm{C}$ (PP2C) phosphatases, thus releasing the subclass III sucrose nonfermenting 1-related kinase 2 (SnRK2s, including SnRK2.2, SnRK2.3, and SnRK2.6) to phosphorylate downstream proteins [91,92]. The arabidopsis protein kinases SnRK2s function as central and positive regulators of the ABA signaling pathway and are involved in stomatal closure, osmotic stress responses, and have an evolutionarily conserved function on plant adaptation to the terrestrial environment [93-95].

Aquatic plants, such as rice, have evolved adaptive mechanisms to survive under submergence. When subjected to flooding, rice or deepwater rice accumulates high ethylene, which activates gibberellin biosynthesis gene SEMIDWARF 1 (SD1), promotes GAdependent elongation, and results in an "escape" strategy to reestablish contact with the air [83]. Recent studies have found that the submergence-induced GA accumulation activates ACCELERATOR OF INTERNODE ELONGATION 1 (ACE1), which confers cells of the intercalary meristematic region with the competence for cell division, leading to internode elongation in the presence of GA. In contrast, high GA repressed DECELERATOR OF INTERNODE ELONGATION 1 (DEC1) suppresses internode elongation, whereas downregulation of DEC1 allows internode elongation [96]. Under submerged conditions, ethylene also induces the expression of two ethylene response factors (ERFs), SNORKEL1 (SK1) and $S K 2$, to trigger remarkable internode elongation via GA [97]. However, the response may vary between species, as GA levels in Rumex acetosa remain unchanged, although ethylene increased during submergence [98]. For the submergence of terrestrial plants, such as $A$. thaliana, the limited gas diffusion causes passive ethylene accumulation, leading to ETHYLENE INSENSITIVE 2 (EIN2) and EIN3/EIN3-like 1 (EIL1)-dependent signaling and enhanced production of the nitric oxide (NO) scavenger PHYTOGLOBIN 1 (PGB1). The enhanced PGB1 levels lead to NO depletion, enhancing group VII ethylene response factor (ERFVII) stability [99]. The constitutively synthesized ERVIIs (e.g., RELATED TO APETALA 2.12 (RAP2.12), RAP2.2, and RAP2.3) redundantly act as the principal activators of many hypoxia adaptive genes and lead to flooding survival [43]. 
Phytohormone signals also play key roles in leaf development. For example, the recruitment of leaf founder cells in the shoot apical meristem (SAM) is mediated by the formation of a concentration maxima of auxin $[100,101]$. Altering the endogenous auxin levels and localization results in leaf simplification in a tomato plant, while downregulating auxin biosynthesis genes (e.g., YUCCA) was reported to inhibit organ initiation in many species such as Arabidopsis, maize, and petunia [102-104]. Cytokinin (CK) also plays an important role in SAM maintenance [105-107]. Overexpression of the CK biosynthesis genes in tomato leaves leads to the formation of highly compound leaves. However, exogenous application of CK causes minor leaf phenotypes in the tomato [108]. Increasing GA levels in tomatoes result in tall plants with larger and simpler leaves [109]. Interestingly, this GA response is not common, and in some species, GA has the opposite effect of inducing more compound leaves $[110,111]$. To better understand the relationship of phytohormones and leaf development, in the next section we will discuss the molecular mechanisms of leaf development.

\section{Mechanisms of Leaf Development: The Gene Regulatory Networks (GRNs)}

Despite the diversity of leaf shapes, the molecular mechanisms of leaf development in most species are shared $[50,107,112,113]$. Recently, the complexity of the genetic networks controlling leaf development was fully summarized [2,114]. Here, we briefly review a classic view of the regulatory pathway which operates in leaf development, in order to better understand the mechanism of leaf plasticity.

Leaves are initiated at the flank of the SAM, which contains a pool of undifferentiated cells at the plant aerial apex [114,115] (Figure 3A). PIN-FORMED 1 (PIN1), the auxin efflux carrier, dynamically repolarizes and creates directional auxin flows at specific positions in the SAM. Auxin locally repressed the expression of class-I KNOTTED-LIKE HOMEOBOX (KNOXI) genes, which are responsible for stem cell maintenance in the SAM, like SHOOTMERISTEMLESS (STM) and BREVIPEDICELLUS (BP) [101,115]. ARP genes (including ASYMMETRIC LEAVES 1 (AS1), ROUGHSHEATH 2, and PHANTASTICA) like AS1 interact with ASYMMETRIC LEAVES 2 (AS2), and their protein complexes bind directly to the promoter of KNOXI genes and repress their expression [116-118]. The formation of an auxin gradient within the SAM also contributes to the formation of boundary domains that separate primordia from the rest of the meristem [114]. These domains are maintained by the activity of several transcription factors, such as the NO APICAL MERISTEM/CUPSHAPED COTYLEDON (NAM/CUC) family [119]. KNOXI transcription factors maintain the meristematic activity in the SAM through CK and GA, by activating the CK biosynthesis gene ISOPENTENYLTRANSFERASE 7 (IPT7), which maintains cell proliferation while preventing cell differentiation by repressing its biosynthesis gene GA 20-oxidase (GA20ox) and activating the deactivation gene GA2ox [22,120].

Starting on the flank of the SAM, the newly initiated leaf primordia becomes asymmetric in three axes: the adaxial-abaxial, medial-lateral, and proximal-distal [122] (Figure 3B). Among these, the adaxial-abaxial polarity allows the further establishment of lateral polarity [114]. To establish adaxial-abaxial polarity, HD-ZIPIII genes expressed in the adaxial side of leaf primordia, function antagonistically to KANADI (KAN) genes, which are expressed in the abaxial side. $Y A B B Y(Y A B)$ functions relatively later in leaf development and acts downstream of KAN genes on the abaxial side [124-127] (Figure 3B). MicroRNAs, like miR165/166, are also expressed towards the abaxial side, negatively regulating HD-ZIPIII to restrict its expression to the adaxial side of leaf primordia [128-130]. In contrast, AS1 and AS2 promote the expression of HD-ZIPIII on the adaxial side and repress the expression of miR165/166, KAN, and $Y A B$ genes [131,132]. Trans-acting short interfering RNAs (ta-siRNAs), whose targets are miR165/166 and Auxin response factors (ARFs) such as ARF3 and ARF4 transcription factors, are generated in the adaxial side and restrict the expression of ARF3/4 genes to the abaxial side [133-135]. 


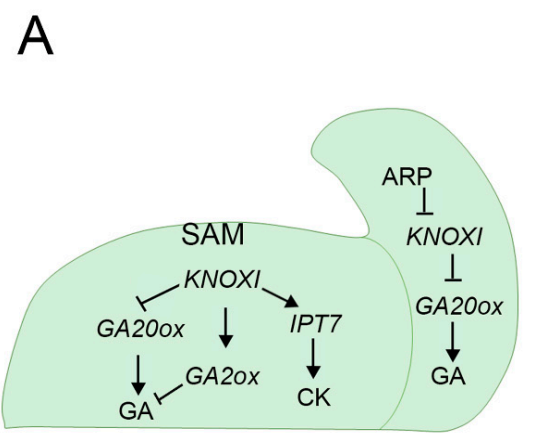

B
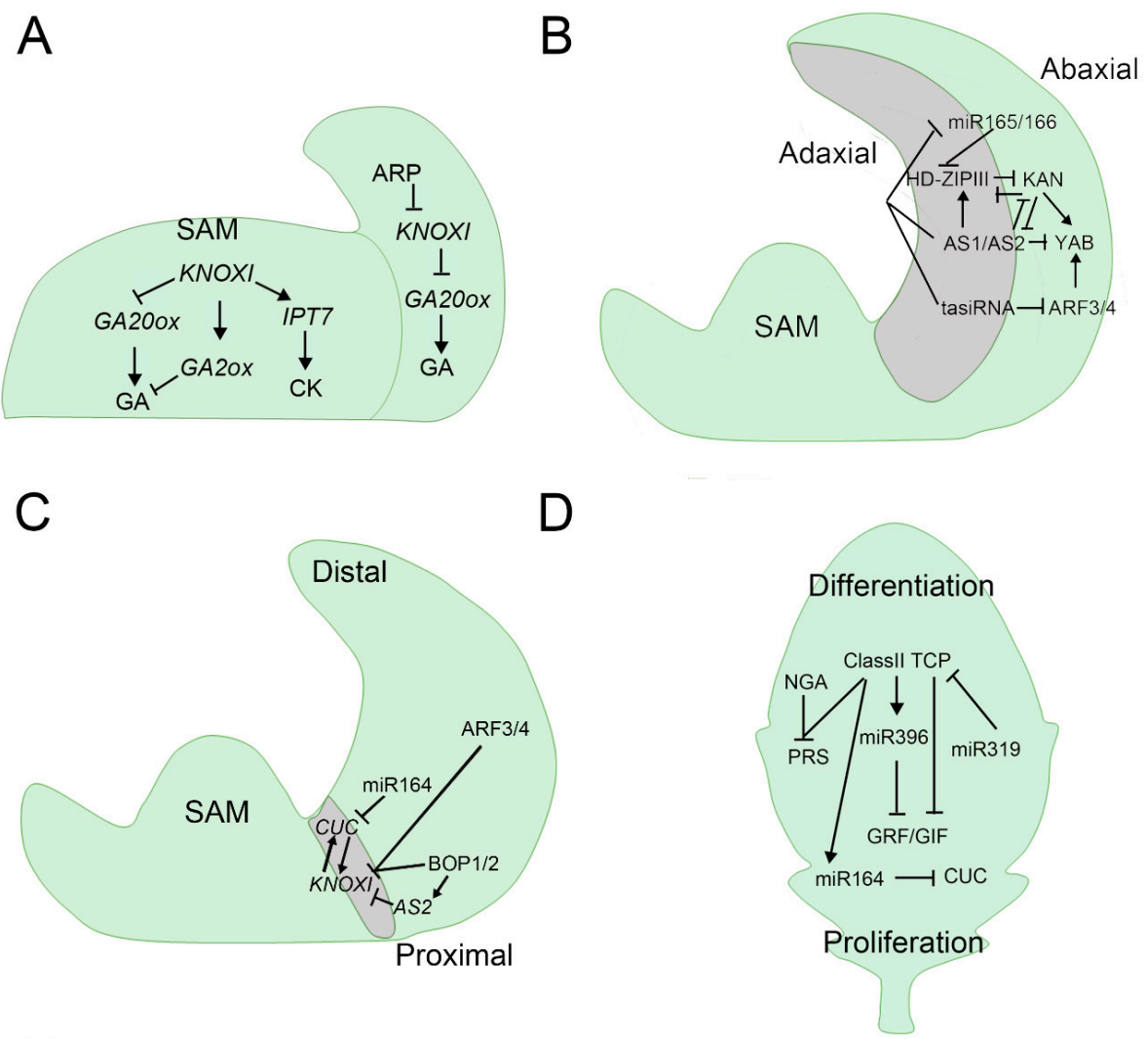

E
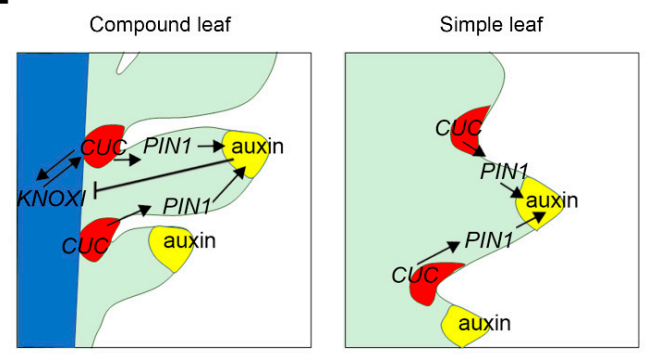

Figure 3. Genetic and hormonal factors that control leaf development. (A) Genetic and hormonal factors are controlling primordium development. Class-I KNOTTED-LIKE HOMEOBOX (KNOXI) proteins maintain high cytokinin (CK) levels and low GA levels in the shoot apical meristem (SAM). ARP maintains high GA level through repression of KNOXI. (B) Adaxial-abaxial polarity establishment in a developing leaf. HD-ZIPIII functions antagonistically to KANADI (KAN) and $Y A B B Y(Y A B)$ acts downstream of KAN on the abaxial side. miR165/166 represses HD-ZIPIII, but ASYMMETRIC LEAVES 1 (AS1) and AS2 promote the expression of HD-ZIPIII on the adaxial side and repress miR165/166, KAN, and YAB. ta-siRNAs target miR165/166 and Auxin response factor 3/4 (ARF3/4) to restrict them to the abaxial side. (C) Proximaldistal polarity establishment in a developing leaf. KNOXI genes are expressed in the boundary region, and CUP-SHAPED COTYLEDONS (CUCs) have positive feedbacks with KNOXI. Blade on PETIOLE 1 (BOP1) and BOP2 are expressed in the proximal region to repress KNOXI directly, or indirectly by AS2. ARF3/4 also repress KNOXI to promote organogenesis at the shoot apex. (D) The switch from cell proliferation to differentiation follows a process that is promoted by the miR319TCP module and repressed by the miR396-GRF module. PRESSED FLOWER (PRS) is also repressed by class II TCP and NGATHA (NGA), promoting cell proliferation in the leaf margin. (E) Common molecular pathways underpin both simple and compound leaf formation. PIN-FORMED 1 (PIN1) localization at the developing leaf is polar so that an auxin activity maximum is formed at the tip of both serration and leaflet. KNOXI are expressed in the rachis of the compound leaf, where they activate CUC expression at the distal boundary of the leaflet and promote polar localization of PIN1 in the leaflets. In turn, CUC activity maintains KNOXI expression in the rachis while auxin downregulates KNOXI expression for leaflet formation. CUC expression and auxin maxima promote the development of serrations. Yellow represents an auxin activity maximum, red the domain of CUC expression, and the blue color denotes the expression domain of KNOXI. Panel A, C, and $\mathrm{D}$ is based on [121] and B is based on [122]. Panel E is based on [123]. 
The proximal-distal axis may be genetically established when a leaf primordium emerges from the shoot apex (Figure 3C). During this process, KNOXI genes are expressed in the boundary region and CUC genes, which are negatively regulated by miR164, have positive feedback with KNOXI [136,137]. KNOXI and AS1 appear to be involved in the proximal-distal polarity patterning, and BLADE ON PETIOLE (BOP) genes, such as $B O P 1$ and $B O P 2$, are expressed in the proximal region, directly repressing KNOXI or indirectly restricting the location of KNOXI by activating AS2 [118,138,139]. In addition, ARF3/4 genes also repress KNOXI to promote organogenesis at the shoot apex [140]. The mechanism of medio-lateral polarity is still not clear, and only a few studies have found several regulatory genes. KANs and HD-ZIPIII antagonize each other and inversely regulate the genes involved in auxin transport and biosynthesis, resulting in a high auxin level in the abaxial domain $[125,141,142]$. The high abaxial auxin and the adaxial expression of MONOPTEROS (MP) results in higher auxin response, therefore, it induced the activation of the WUSCHEL- related homeobox (WOX) genes, WOX1 and PRESSEDFLOWER (PRS) [141,142]. The expression of WOX1 and PRS is restricted to the middle domain but highly expressed in the marginal region, promoting the formation of serration or leaflets [50,121,143-145].

After leaf blade initiation, leaves grow according to two main processes based on cell division and expansion (Figure 3D). Two classes of miRNA/transcription factors play antagonistic roles in cell proliferation and differentiation for subsequent leaf development (Figure 3D). The class II TEOSINTE BRANCHED1/CYCLOIDEA/PROLIFERATING CELL FACTOR (TCP), which are downregulated by miR319, function to promote cell differentiation and expansion in the distal part of leaves [146], while GROWTH REGULATING FACTORS (GRFs), which are repressed by miR396, function with GRF interacting factors (GIFs) to promote cell proliferation in the proximal ends of leaves [147-149]. Class II TCP, like TCP4, can also directly activate miR396 to inhibit the expression of GRF targets or repress the expression of GRF/GIF genes via unknown mechanisms [148,150,151]. CUC genes play key roles for marginal morphogenesis and are repressed by Class II TCP and miR164 [152-154]. In addition, PRS is also repressed by class II TCP and NGATHA (NGA), promoting cell proliferation in the leaf margin [155]. Recent studies also found that WOX1 regulates Class II TCP at both the transcriptional and translational level and regulates leaf size and vein pattern in Cucumis satious [156].

There are significant differences in simple-leafed and compound-leafed species (Figure 3E). Although in some leguminous lineages LEAFY (LFY) activity modulates leaf complexity [157], KNOXI genes are the key factors regulating leaf morphological differences among species $[40,115]$. In simple-leafed species like A. thaliana, KNOXI is only expressed in the SAM, and marginal serrations are modified by the feedback regulation of auxin maxima and CUC genes [158]. Correspondingly, in compound-leafed species like tomato and Cardamine hirsute, KNOXI is re-activated in the leaf primordia, which results in the formation of leaflets by the feedback regulation of auxin maxima, KNOXI, and CUC genes $[101,123,159]$.

\section{Molecular Mechanisms of Heterophylly-A Representative of Leaf Plasticity}

Environmental signals were integrated into GRNs and subsequently induced rapid and acclimated changes. Morphological plasticity was found in many species, as shown by changing leaf size, shape and thickness, and stomatal density, which has been seen in several species under different conditions or development stages [50,112,113,160]. Among those, heterophyllous plants show extreme plasticity in response to environmental factors, and were regarded as an ideal system for studying environmentally induced leaf plasticity $[3,11,86]$. To achieve various leaf patterns with different environments, heterophyllous plants have evolved diverse mechanisms for leaf development (Figure 4). The first illustrated example is R. aquatica, which develops deeply dissected leaves under submerged or low temperature conditions, while it has shallow serrated leaves under terrestrial or high temperature conditions [10]. It was found that the expression levels of KNOXI, which is the 
key gene that decides the final leaf form in many plant species, upregulated in submergence and low temperature but downregulated in terrestrial and high temperature conditions. Thus, due to the conserved function of KNOXI in activating CK and repressing GA accumulation (see Sections 3 and 4), the phytohormone pattern changes in leaf primordia therefore regulate the final leaf shape [40]. Interestingly, R. aquatica also develops deeply dissected leaves in high illumination and shows high expression of KNOXI, indicating a potential relationship of KNOXI and light response [40].

In another heterophyllous plant Ranunculus trichophyllus, ABA and ethylene mainly control terrestrial and aquatic leaf development, respectively. In terrestrial conditions, high ABA induced the ABSCISIC ACID INSENSITIVE 3 (ABI3)-mediated activation of adaxial genes (e.g., HD-ZIPIII), which then increased the expression of STOMAGEN (STO) and VASCULAR-RELATED NAC-DOMAIN 7 (VND7), resulting in increased stomata density and vessel elements. In contrast, submerged conditions activated ethylene synthesis and accumulation, which then induced the expression of EIN3-mediated activation of abaxial genes (e.g., $K A N$ ) and repressed $S T O$ and $V N D 7$, resulting in a lack of stomata and reduced vessel development in submerged leaves [12]. Recently, studies on Potamogeton wrightii (heterophyllous) and its sister species P. perfoliatus (homophyllous) have shown that exogenous ABA application induced stomata in both submerged species, $P$. perfoliatus as well as in heterophyllous $P$. wrightii [85]. However, under salinity stress, which promotes ABA biosynthesis by NCEDs, stomata were only induced in P. wrightii, but not in P. perfoliatus. These results suggested that differences in the ABA-mediated stress responses were responsible for the variation in morphological plasticity between the two Potamogeton plants under natural conditions [85].

Morphological plasticity in the genus Capsella, such as the increased leaf complexity induced by low temperatures, is mediated by the activation of REDUCED COMPLEXITY (RCO) [161]. Recent studies in A. thaliana and its relative $C$. hirsuta have shown that the different leaflet development also requires $R C O$, evolved in the Brassicaceae family through gene duplication, and was lost in A. thaliana, contributing to leaf simplification in this species [161,162]. RCO functions specifically in leaf development, where it represses the cell growth at flanks [161,162]. Subsequently, researchers have found that differences in the leaf originate from two distinct processes that act in the $C$. hirsuta, but not in the $A$. thaliana leaves. Firstly, KNOXI gene (e.g., STM) delayed differentiation but increased the size and number of leaf protrusions. Secondly, RCO leads to growth differences created by the inhibition of marginal patterning [163]. RCO also coordinates the homeostasis of the phytohormone $\mathrm{CK}$ through CK biosynthesis and catabolism and their coordinates are essential for complex leaf development in C. hirsuta [164,165]. However, whether the morphological plasticity in C. grandiflora is achieved by the RCO/CK module is still unknown.

Even though heterophylly has been seen for centuries, the molecular mechanisms of these plants are still largely unknown. Recent advances in omics technologies and gene transformation have allowed genetic analyses of many heterophyllous species, which make it possible to investigate the mechanisms of plant development, morphological plasticity, and environmental adaption [3,13]. For example, Potamogeton octandrus is an aquatic heterophyllous plant that has ovate and flat floating leaves, but narrow and thin submerged leaves. Transcriptome analyses have found that many of the different expression genes (DEGs) were found in the "plant hormone signal transduction" category and endogenous levels of hormones such as ABA, cytokinin, GA, and auxin changed between conditions [16]. Comparative transcriptomics also reveals genes related to physiological adaptions of two accessions of $R$. aquatica, indicating that different genotypes might develop a novel strategy for adaptation [166].

Based on the above, we have found that key genes and phytohormones function in leaf development, and environmental responses play an important role in leaf plasticity [167-169]. There are still questions: If key genes involved in heterophylly (e.g., KNOXI) have conserved roles among species, why are some plants able to develop heterophylly 
for environmental adaption while others cannot? Do non-coding RNA and cis-acting regulatory elements function to regulate the morphological plasticity?

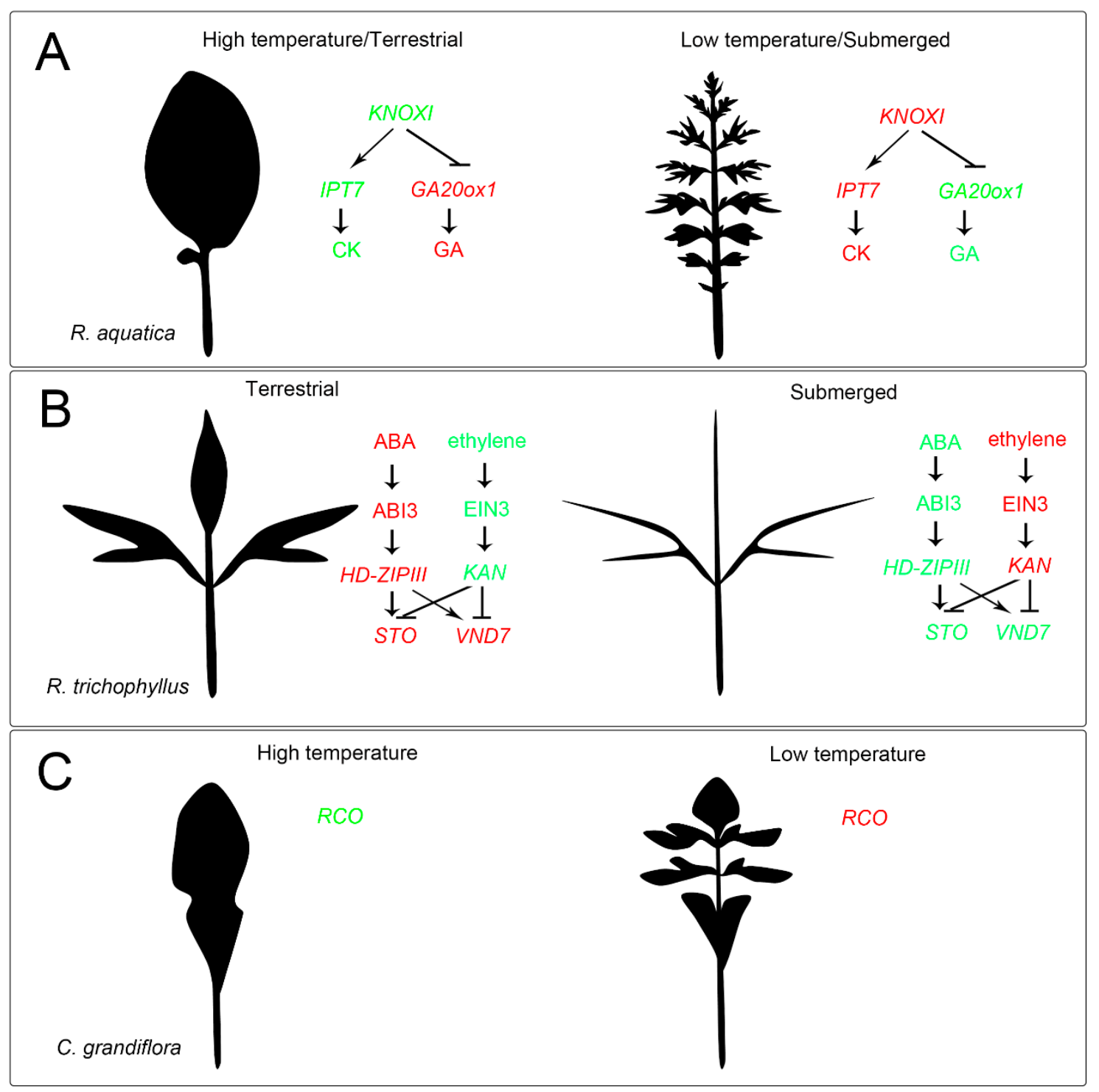

Figure 4. Molecular mechanisms of heterophylly. (A) The mechanism of heterophylly in R. aquatica. Complex leaves were induced by the upregulated KNOXI and thus induced repression of Ga20ox1 and downregulated GA, while simple leaves were induced by the downregulated KNOXI and thus induced upregulated Ga20ox1 and GA. KNOXI also induced the accumulation of CK by the regulation of ISOPENTENYLTRANSFERASE 7 (IPT7). (B) The mechanism of heterophylly in R. trichophyllus. Terrestrial conditions induced ABA accumulation and activates HD-ZIPIII-mediated STOMAGEN (STO) and VASCULAR-RELATED NAC-DOMAIN 7 (VND7) upregulation via ABI3, while submerged conditions induced ethylene accumulation and activate KAN-mediated STO and VND7 downregulation via EIN3. (C) The heterophylly of C. grandiflora was induced by the temperature, dependent on REDUCED COMPLEXITY (RCO). Red in (A-C) represents upregulated genes or accumulated phytohormones, and green in $(A-C)$ represents downregulated genes or phytohormones.

\section{Future Perspectives}

In a rapidly changing climate, plants are facing great challenges from the environment. Recent advances in omics technologies and gene transformation have allowed genetic analyses to investigate the molecular mechanisms of plant development, ecology, and evolution [3,170]. Recent works also have made great breakthroughs in the fields of environmental signals sensing [171-173], phytohormone interactive networks [29], and 
plant stress combinations $[174,175]$. Until now, the molecular mechanisms underlying leaf development have been extensively elucidated $[114,176]$. However, the large number of mechanisms of environmentally induced leaf plasticity are still unknown, which limits the application of morphological variety in plant improvement. Thus, the identification of key genes from genomics, transcriptomics, and phenomics, or CRISPR-mediated gene editing, is also a powerful and efficient approach to discover the novel mechanisms underlying plant environmental adaptation. Identifying the developmental and genetic basis of leaf plasticity induced by environmental changes will be important to engineer more adaptive crops in the face of future global change.

Author Contributions: G.L., S.H., X.Z., S.K., Y.L., J.Y., H.H.; writing-original draft preparation, G.L., S.K., J.Y., H.H.; writing-review and editing. All authors have read and agreed to the published version of the manuscript.

Funding: This research was supported by the National Key Research and Development Program of China (2017YFE0128800, 2018YFD0900801), National Natural Science Foundation of China (31870384), and China Postdoctoral Science Foundation Funded Project (2020M672444).

Acknowledgments: Because of space constraints, we apologize to all colleagues whose work and publications have not been mentioned and cited.

Conflicts of Interest: The authors declare no conflict of interest.

\section{References}

1. Nakayama, H.; Kimura, S. Leaves may function as temperature sensors in the heterophylly of Rorippa aquatica (Brassicaceae). Plant Signal. Behav. 2015, 10, e1091909. [CrossRef] [PubMed]

2. Conklin, P.A.; Strable, J.; Li, S.; Scanlon, M.J. On the mechanisms of development in monocot and eudicot leaves. New Phytol. 2019, 221, 706-724. [CrossRef] [PubMed]

3. Li, G.; Hu, S.; Hou, H.; Kimura, S. Heterophylly: Phenotypic plasticity of leaf shape in aquatic and amphibious plants. Plants 2019, 8, 420. [CrossRef] [PubMed]

4. Bar, M.; Ori, N. Leaf development and morphogenesis. Development 2014, 141, 4219-4230. [CrossRef]

5. Chitwood, D.H.; Sinha, N.R. Evolutionary and environmental forces sculpting leaf development. Curr. Biol. 2016, 26, 297-306. [CrossRef] [PubMed]

6. Tsukaya, H. Leaf shape diversity with an emphasis on leaf contour variation, developmental background, and adaptation. Semin. Cell Dev. Biol. 2018, 79, 48-57. [CrossRef]

7. Gratani, L. Plant phenotypic plasticity in response to environmental factors. Adv. Bot. 2014, 4, 1-17. [CrossRef]

8. Sultan, S.E. Developmental plasticity: Re-conceiving the genotype. Interface Focus 2017, 7, 20170009. [CrossRef]

9. Zotz, G.; Wilhelm, K.; Becker, A. Heteroblasty-A review. Bot. Rev. 2011, 77, 109-151. [CrossRef]

10. Nakayama, H.; Nakayama, N.; Nakamasu, A.; Sinha, N.; Kimura, S. Toward elucidating the mechanisms that regulate heterophylly. Plant Morphol. 2012, 24, 57-63. [CrossRef]

11. Nakayama, H.; Sinha, N.R.; Kimura, S. How do plants and phytohormones accomplish heterophylly, leaf phenotypic plasticity, in response to environmental cues. Front. Plant Sci. 2017, 8, 1717. [CrossRef] [PubMed]

12. Kim, J.; Joo, Y.; Kyung, J.; Jeon, M.; Park, J.Y.; Lee, H.G.; Chung, D.S.; Lee, E.; Lee, I. A molecular basis behind heterophylly in an amphibious plant, Ranunculus trichophyllus. PLoS Genet. 2018, 14, e1007208. [CrossRef] [PubMed]

13. Li, G.; Hu, S.; Yang, J.; Zhao, X.; Kimura, S.; Schultz, E.A.; Hou, H. Establishment of an Agrobacterium mediated transformation protocol for the detection of cytokinin in the heterophyllous plant Hygrophila difformis (Acanthaceae). Plant Cell Rep. 2020, 39, 737-750. [CrossRef] [PubMed]

14. Manuela, D.; Xu, M. Juvenile leaves or adult leaves: Determinants for vegetative phase change in higher plants. Int. J. Mol. Sci. 2020, 21, 9753. [CrossRef] [PubMed]

15. He, D.; Guo, P.; Gugger, P.F.; Guo, Y.; Liu, X.; Chen, J. Investigating the molecular basis for heterophylly in the aquatic plant Potamogeton octandrus (Potamogetonaceae) with comparative transcriptomics. PeerJ 2018, 6, e4448. [CrossRef]

16. Tsukaya, H. Leaf shape: Genetic controls and environmental factors. Int. J. Dev. Biol. 2005, 49, 547-555. [CrossRef]

17. Sanz, L.; Albertos, P.; Mateos, I.; Sanchez-Vicente, I.; Lechon, T.; Fernandez-Marcos, M.; Lorenzo, O. Nitric oxide (NO) and phytohormones crosstalk during early plant development. J. Exp. Bot. 2015, 66, 2857-2868. [CrossRef]

18. Huang, H.; Liu, B.; Liu, L.; Song, S. Jasmonate action in plant growth and development. J. Exp. Bot. 2017, 68, 1349-1359. [CrossRef]

19. Kieber, J.J.; Schaller, G.E. Cytokinin signaling in plant development. Development 2018, 145, dev149344. [CrossRef]

20. Ullah, A.; Manghwar, H.; Shaban, M.; Khan, A.H.; Akbar, A.; Ali, U.; Ali, E.; Fahad, S. Phytohormones enhanced drought tolerance in plants: A coping strategy. Environ. Sci. Pollut. Res. Int. 2018, 25, 33103-33118. [CrossRef] 
21. Peres, A.; Soares, J.S.; Tavares, R.G.; Righetto, G.; Zullo, M.A.T.; Mandava, N.B.; Menossi, M. Brassinosteroids, the sixth class of phytohormones: A molecular view from the discovery to hormonal interactions in plant development and stress adaptation. Int. J. Mol. Sci. 2019, 20, 331. [CrossRef] [PubMed]

22. Jasinski, S.; Piazza, P.; Craft, J.; Hay, A.; Woolley, L.; Rieu, I.; Phillips, A.; Hedden, P.; Tsiantis, M. KNOX action in Arabidopsis is mediated by coordinate regulation of cytokinin and gibberellin activities. Curr. Biol. 2005, 15, 1560-1565. [CrossRef]

23. Su, Y.; Liu, Y.; Zhang, X. Auxin-cytokinin interaction regulates meristem development. Mol. Plant 2011, 4, 616-625. [CrossRef] [PubMed]

24. Vanstraelen, M.; Benkova, E. Hormonal interactions in the regulation of plant development. Annu. Rev. Cell Dev. Biol. 2012, 28, 463-487. [CrossRef]

25. Zhu, Z.; Lee, B. Friends or foes: New insights in jasmonate and ethylene co-actions. Plant Cell Physiol. 2015, 56, 414-420. [CrossRef] [PubMed]

26. Nguyen, T.N.; Tuan, P.A.; Mukherjee, S.; Son, S.; Ayele, B.T. Hormonal regulation in adventitious roots and during their emergence under waterlogged conditions in wheat. J. Exp. Bot. 2018, 69, 4065-4082. [CrossRef]

27. Kohli, A.; Sreenivasulu, N.; Lakshmanan, P.; Kumar, P.P. The phytohormone crosstalk paradigm takes center stage in understanding how plants respond to abiotic stresses. Plant Cell Rep. 2013, 32, 945-957. [CrossRef]

28. Fahad, S.; Hussain, S.; Bano, A.; Saud, S.; Hassan, S.; Shan, D.; Khan, F.A.; Khan, F.; Chen, Y.; Wu, C.; et al. Potential role of phytohormones and plant growth-promoting rhizobacteria in abiotic stresses: Consequences for changing environment. Environ. Sci. Pollut. Res. Int. 2015, 22, 4907-4921. [CrossRef]

29. Altmann, M.; Altmann, S.; Rodriguez, P.A.; Weller, B.; Elorduy Vergara, L.; Palme, J.; Marin-de la Rosa, N.; Sauer, M.; Wenig, M.; Villaecija-Aguilar, J.A.; et al. Extensive signal integration by the phytohormone protein network. Nature 2020, 583, 271-276. [CrossRef]

30. Phukan, U.J.; Mishra, S.; Shukla, R.K. Waterlogging and submergence stress: Affects and acclimation. Crit. Rev. Biotechnol. 2016, 36, 956-966. [CrossRef]

31. Brunetti, C.; Sebastiani, F.; Tattini, M. Review: ABA, flavonols, and the evolvability of land plants. Plant Sci. 2019, 280, 448-454. [CrossRef] [PubMed]

32. Ort, D. When there is too much light. Plant Physiol. 2001, 125, 29-32. [CrossRef] [PubMed]

33. Weraduwage, S.M.; Chen, J.; Anozie, F.C.; Morales, A.; Weise, S.E.; Sharkey, T.D. The relationship between leaf area growth and biomass accumulation in Arabidopsis thaliana. Front. Plant Sci. 2015, 6, 167. [CrossRef] [PubMed]

34. Casal, J.J. Photoreceptor signaling networks in plant responses to shade. Annu. Rev. Plant Biol. 2013, 64, 403-427. [CrossRef]

35. Pantazopoulou, C.K.; Bongers, F.J.; Kupers, J.; Reinen, E.; Das, D.; Evers, J.B.; Anten, N.; Pierik, R. Neighbor detection at the leaf tip adaptively regulates upward leaf movement through spatial auxin dynamics. Proc. Natl. Acad. Sci. USA 2017, 114, 7450-7455. [CrossRef] [PubMed]

36. Carabelli, M.; Possenti, M.; Sessa, G.; Ciolfi, A.; Sassi, M.; Morelli, G.; Ruberti, I. Canopy shade causes a rapid and transient arrest in leaf development through auxin-induced cytokinin oxidase activity. Genes Dev. 2007, 21, 1863-1868. [CrossRef]

37. Lake, J.; Quick, W.; Beerling, D.; Woodward, I. Plant development-Signals from mature to new leaves. Nature 2001, 411, 154. [CrossRef]

38. Yano, S.; Terashima, I. Developmental process of sun and shade leaves in Chenopodium album L. Plant Cell Environ. 2004, 27, 781-793. [CrossRef]

39. Casson, S.A.; Franklin, K.A.; Gray, J.E.; Grierson, C.S.; Whitelam, G.C.; Hetherington, A.M. phytochrome B and PIF4 regulate stomatal development in response to light quantity. Curr. Biol. 2009, 19, 229-234. [CrossRef]

40. Nakayama, H.; Nakayama, N.; Seiki, S.; Kojima, M.; Sakakibara, H.; Sinha, N.; Kimura, S. Regulation of the KNOX-GA gene module induces heterophyllic alteration in North American lake cress. Plant Cell 2014, 26, 4733-4748. [CrossRef]

41. Mommer, L.; Pons, T.L.; Wolters-Arts, M.; Venema, J.H.; Visser, E.J. Submergence-induced morphological, anatomical, and biochemical responses in a terrestrial species affect gas diffusion resistance and photosynthetic performance. Plant Physiol. 2005, 139, 497-508. [CrossRef] [PubMed]

42. Horiguchi, G.; Nemoto, K.; Yokoyama, T.; Hirotsu, N. Photosynthetic acclimation of terrestrial and submerged leaves in the amphibious plant Hygrophila difformis. AoB Plants 2019, 11, plz009. [CrossRef] [PubMed]

43. Hartman, S.; Liu, Z.; van Veen, H.; Vicente, J.; Reinen, E.; Martopawiro, S.; Zhang, H.; van Dongen, N.; Bosman, F.; Bassel, G.W.; et al. Ethylene-mediated nitric oxide depletion pre-adapts plants to hypoxia stress. Nat. Commun. 2019, 10, 4020. [CrossRef] [PubMed]

44. Wallenstein, A.; Albert, L. Plant morphology: Its control in Proserpinaca by photoperiod, temperature, and gibberellic acid. Science 1963, 140, 998-1000. [CrossRef] [PubMed]

45. COOK, C. On the determination of leaf form in Ranunculus aquatilis. New Phytol. 1969, 68, 469-480. [CrossRef]

46. Ibanez, C.; Poeschl, Y.; Peterson, T.; Bellstadt, J.; Denk, K.; Gogol-Doring, A.; Quint, M.; Delker, C. Ambient temperature and genotype differentially affect developmental and phenotypic plasticity in Arabidopsis thaliana. BMC Plant Biol. 2017, 17, 114. [CrossRef]

47. Quint, M.; Delker, C.; Franklin, K.A.; Wigge, P.A.; Halliday, K.J.; van Zanten, M. Molecular and genetic control of plant thermomorphogenesis. Nat. Plants 2016, 2, 15190. [CrossRef]

48. Casal, J.J.; Balasubramanian, S. Thermomorphogenesis. Annu Rev. Plant Biol. 2019, 70, 321-346. [CrossRef]

49. Erwin, J.; Heins, R.; Karlsson, M. Thermomorphogenesis in Lilium longiflorum. Am. J. Bot. 1989, 76, 47-52. [CrossRef]

50. Fritz, M.A.; Rosa, S.; Sicard, A. Mechanisms underlying the environmentally induced plasticity of leaf morphology. Front. Genet. 2018, 9, 478. [CrossRef]

51. Crawford, A.J.; McLachlan, D.H.; Hetherington, A.M.; Franklin, K.A. High temperature exposure increases plant cooling capacity. Curr. Biol. 2012, 22, R396-R397. [CrossRef] [PubMed] 
52. Bridge, L.J.; Franklin, K.A.; Homer, M.E. Impact of plant shoot architecture on leaf cooling: A coupled heat and mass transfer model. J. R. Soc. Interface 2013, 10, 20130326. [CrossRef] [PubMed]

53. Bailey, I.W.; Sinnott, E.W. The climatic distribution of certain types of angiosperm leaves. Am. J. Bot. 1916, 3, 24-39. [CrossRef]

54. Webb, L. Environmental relationships of the structural types of Australian rain forest vegetation. Ecology 1968, 49, 296. [CrossRef]

55. Royer, D.L.; Meyerson, L.A.; Robertson, K.M.; Adams, J.M. Phenotypic plasticity of leaf shape along a temperature gradient in Acer rubrum. PLoS ONE 2009, 4, e7653. [CrossRef]

56. Peppe, D.J.; Royer, D.L.; Cariglino, B.; Oliver, S.Y.; Newman, S.; Leight, E.; Enikolopov, G.; Fernandez-Burgos, M.; Herrera, F.; Adams, J.M.; et al. Sensitivity of leaf size and shape to climate: Global patterns and paleoclimatic applications. New Phytol. 2011, 190, 724-739. [CrossRef]

57. Chitwood, D.H.; Rundell, S.M.; Li, D.Y.; Woodford, Q.L.; Yu, T.T.; Lopez, J.R.; Greenblatt, D.; Kang, J.; Londo, J.P. Climate and developmental plasticity: Interannual variability in grapevine leaf morphology. Plant Physiol. 2016, 170, 1480-1491. [CrossRef]

58. Little, S.A.; Kembel, S.W.; Wilf, P. Paleotemperature proxies from leaf fossils reinterpreted in light of evolutionary history. PLoS ONE 2010, 5, e15161. [CrossRef]

59. Amano, R.; Nakayama, H.; Morohoshi, Y.; Kawakatsu, Y.; Ferjani, A.; Kimura, S. A decrease in ambient temperature induces post-mitotic enlargement of palisade cells in North American Lake Cress. PLoS ONE 2015, 10, e0141247. [CrossRef]

60. Sato, M.; Tsutsumi, M.; Ohtsubo, A.; Nishii, K.; Kuwabara, A.; Nagata, T. Temperature-dependent changes of cell shape during heterophyllous leaf formation in Ludwigia arcuata (Onagraceae). Planta 2008, 228, 27-36. [CrossRef]

61. Haas, K.; Wightman, R.; Meyerowitz, E.; Peaucelle, A. Pectin homogalacturonan nanofilament expansion drives morphogenesis in plant epidermal cells. Science 2020, 367, 1003-1007. [CrossRef]

62. Li, Y.; Deng, M.; Liu, H.; Li, Y.; Chen, Y.; Jia, M.; Xue, H.; Shao, J.; Zhao, J.; Qi, Y.; et al. ABNORMAL SHOOT 6 interacts with KATANIN 1 and SHADE AVOIDANCE 4 to promote cortical microtubule severing and ordering in Arabidopsis. J. Integr. Plant Biol. 2020. [CrossRef] [PubMed]

63. Delker, C.; Sonntag, L.; James, G.V.; Janitza, P.; Ibanez, C.; Ziermann, H.; Peterson, T.; Denk, K.; Mull, S.; Ziegler, J.; et al. The DET1-COP1-HY5 pathway constitutes a multipurpose signaling module regulating plant photomorphogenesis and thermomorphogenesis. Cell Rep. 2014, 9, 1983-1989. [CrossRef] [PubMed]

64. Bellstaedt, J.; Trenner, J.; Lippmann, R.; Poeschl, Y.; Zhang, X.; Friml, J.; Quint, M.; Delker, C. A mobile auxin signal connects temperature sensing in cotyledons with growth responses in hypocotyls. Plant Physiol. 2019, 180, 757-766. [CrossRef] [PubMed]

65. Koini, M.A.; Alvey, L.; Allen, T.; Tilley, C.A.; Harberd, N.P.; Whitelam, G.C.; Franklin, K.A. High temperature-mediated adaptations in plant architecture require the bHLH transcription factor PIF4. Curr. Biol. 2009, 19, 408-413. [CrossRef] [PubMed]

66. Stavang, J.A.; Gallego-Bartolome, J.; Gomez, M.D.; Yoshida, S.; Asami, T.; Olsen, J.E.; Garcia-Martinez, J.L.; Alabadi, D.; Blazquez, M.A. Hormonal regulation of temperature-induced growth in Arabidopsis. Plant J. 2009, 60, 589-601. [CrossRef] [PubMed]

67. Franklin, K.A.; Lee, S.H.; Patel, D.; Kumar, S.V.; Spartz, A.K.; Gu, C.; Ye, S.; Yu, P.; Breen, G.; Cohen, J.D.; et al. Phytochrome-interacting factor 4 (PIF4) regulates auxin biosynthesis at high temperature. Proc. Natl. Acad. Sci. USA 2011, 108, 20231-20235. [CrossRef]

68. Sun, J.; Qi, L.; Li, Y.; Chu, J.; Li, C. PIF4-mediated activation of YUCCA8 expression integrates temperature into the auxin pathway in regulating arabidopsis hypocotyl growth. PLoS Genet. 2012, 8, e1002594. [CrossRef]

69. Box, M.S.; Huang, B.E.; Domijan, M.; Jaeger, K.E.; Khattak, A.K.; Yoo, S.J.; Sedivy, E.L.; Jones, D.M.; Hearn, T.J.; Webb, A.A.R.; et al. ELF3 controls thermoresponsive growth in Arabidopsis. Curr. Biol. 2015, 25, 194-199. [CrossRef]

70. Mizuno, T.; Nomoto, Y.; Oka, H.; Kitayama, M.; Takeuchi, A.; Tsubouchi, M.; Yamashino, T. Ambient temperature signal feeds into the circadian clock transcriptional circuitry through the EC night-time repressor in Arabidopsis thaliana. Plant Cell Physiol. 2014, 55, 958-976. [CrossRef]

71. Ibanez, C.; Delker, C.; Martinez, C.; Burstenbinder, K.; Janitza, P.; Lippmann, R.; Ludwig, W.; Sun, H.; James, G.V.; Klecker, M.; et al. Brassinosteroids dominate hormonal regulation of plant thermomorphogenesis via BZR1. Curr. Biol. 2018, 28, 303-310.e303. [CrossRef] [PubMed]

72. Martinez, C.; Espinosa-Ruiz, A.; de Lucas, M.; Bernardo-Garcia, S.; Franco-Zorrilla, J.M.; Prat, S. PIF4-induced BR synthesis is critical to diurnal and thermomorphogenic growth. EMBO J. 2018, 37, e99552. [CrossRef] [PubMed]

73. Mizutani, M.; Kanaoka, M.M. Environmental sensing and morphological plasticity in plants. Semin. Cell Dev. Biol. 2018, 83, 69-77. [CrossRef] [PubMed]

74. Lorrain, S.; Allen, T.; Duek, P.D.; Whitelam, G.C.; Fankhauser, C. Phytochrome-mediated inhibition of shade avoidance involves degradation of growth-promoting bHLH transcription factors. Plant J. 2008, 53, 312-323. [CrossRef] [PubMed]

75. de Lucas, M.; Daviere, J.M.; Rodriguez-Falcon, M.; Pontin, M.; Iglesias-Pedraz, J.M.; Lorrain, S.; Fankhauser, C.; Blazquez, M.A.; Titarenko, E.; Prat, S. A molecular framework for light and gibberellin control of cell elongation. Nature 2008, 451, 480-484. [CrossRef]

76. Feng, S.; Martinez, C.; Gusmaroli, G.; Wang, Y.; Zhou, J.; Wang, F.; Chen, L.; Yu, L.; Iglesias-Pedraz, J.M.; Kircher, S.; et al. Coordinated regulation of Arabidopsis thaliana development by light and gibberellins. Nature 2008, 451, 475-479. [CrossRef] [PubMed]

77. Guzman, P.; Ecker, J. Exploiting the triple response of Arabidopsis to identify ethylene-related mutants. Plant Cell 1990, 2, 513-523.

78. Sakuraba, Y.; Jeong, J.; Kang, M.Y.; Kim, J.; Paek, N.C.; Choi, G. Phytochrome-interacting transcription factors PIF4 and PIF5 induce leaf senescence in Arabidopsis. Nat. Commun. 2014, 5, 4636. [CrossRef]

79. Song, Y.; Yang, C.; Gao, S.; Zhang, W.; Li, L.; Kuai, B. Age-triggered and dark-induced leaf senescence require the bHLH transcription factors PIF3, 4, and 5. Mol. Plant 2014, 7, 1776-1787. [CrossRef]

80. Franklin, K.A. Light and temperature signal crosstalk in plant development. Curr. Opin. Plant Biol. 2009, 12, 63-68. [CrossRef] 
81. Kostaki, K.I.; Coupel-Ledru, A.; Bonnell, V.C.; Gustavsson, M.; Sun, P.; McLaughlin, F.J.; Fraser, D.P.; McLachlan, D.H.; Hetherington, A.M.; Dodd, A.N.; et al. Guard cells integrate light and temperature signals to control stomatal aperture. Plant Physiol. 2020, 182, 1404-1419. [CrossRef] [PubMed]

82. Tang, H.; Bi, H.; Liu, B.; Lou, S.; Song, Y.; Tong, S.; Chen, N.; Jiang, Y.; Liu, J.; Liu, H. WRKY33 interacts with WRKY12 protein to up-regulate RAP2.2 during submergence induced hypoxia response in Arabidopsis thaliana. New Phytol. 2021, 229, 106-125. [CrossRef] [PubMed]

83. Kuroha, T.; Nagai, K.; Gamuyao, R.; Wang, D.; Furuta, T.; Nakamori, M.; Kitaoka, T.; Adachi, K.; Minami, A.; Mori, Y.; et al. Ethylene-gibberellin signaling underlies adaptation of rice to periodic flooding. Science 2018, 361, 181-186. [CrossRef] [PubMed]

84. Robionek, A.; Banas, K.; Chmara, R.; Szmeja, J. The avoidance strategy of environmental constraints by an aquatic plant Potamogeton alpinus in running waters. Ecol. Evol. 2015, 5, 3327-3337. [CrossRef] [PubMed]

85. Iida, S.; Ikeda, M.; Amano, M.; Sakayama, H.; Kadono, Y.; Kosuge, K. Loss of heterophylly in aquatic plants: Not ABA-mediated stress but exogenous ABA treatment induces stomatal leaves in Potamogeton perfoliatus. J. Plant Res. 2016, 129, 853-862. [CrossRef]

86. Wanke, D. The ABA-mediated switch between submersed and emersed life-styles in aquatic macrophytes. J. Plant Res. 2011, 124, 467-475. [CrossRef]

87. van Veen, H.; Sasidharan, R. Shape shifting by amphibious plants in dynamic hydrological niches. New Phytol. 2021, 229, 79-84. [CrossRef]

88. Mitsui, Y.; Nomura, N.; Isagi, Y.; Tobe, H.; Setoguchi, H. Ecological barriers to gene flow between riparian and forest species of Ainsliaea (Asteraceae). Evolution 2011, 65, 335-349. [CrossRef]

89. Tuteja, N. Abscisic acid and abiotic stress signaling. Plant Sig. Behav. 2007, 2, 135-138. [CrossRef]

90. Nakashima, K.; Yamaguchi-Shinozaki, K. ABA signaling in stress-response and seed development. Plant Cell Rep. 2013, 32, 959-970. [CrossRef]

91. Ma-Lauer, Y.; Szostkiewicz, I.; Korte, A.; Moes, D.; Yang, Y.; Christmann, A.; Grill, E. Regulators of PP2C phosphatase activity function as abscisic acid sensors. Science 2009, 324, 1064-1068.

92. Park, S.Y.; Fung, P.; Nishimura, N.; Jensen, D.R.; Fujii, H.; Zhao, Y.; Lumba, S.; Santiago, J.; Rodrigues, A.; Chow, T.F.; et al. Abscisic acid inhibits type 2C protein phosphatases via the PYR/PYL family of START proteins. Science 2009, 324, $1068-1071$. [CrossRef] [PubMed]

93. Nakashima, K.; Fujita, Y.; Kanamori, N.; Katagiri, T.; Umezawa, T.; Kidokoro, S.; Maruyama, K.; Yoshida, T.; Ishiyama, K.; Kobayashi, M.; et al. Three Arabidopsis SnRK2 protein kinases, SRK2D/SnRK2.2, SRK2E/SnRK2.6/OST1 and SRK2I/SnRK2.3, involved in ABA signaling are essential for the control of seed development and dormancy. Plant Cell Physiol. 2009, 50, 1345-1363. [CrossRef]

94. Fujii, H.; Zhu, J. Arabidopsis mutant deficient in 3 abscisic acid-activated protein kinases reveals critical roles in growth, reproduction, and stress. Proc. Natl. Acad. Sci. USA 2009, 106, 8380-8385. [CrossRef] [PubMed]

95. Shinozawa, A.; Otake, R.; Takezawa, D.; Umezawa, T.; Komatsu, K.; Tanaka, K.; Amagai, A.; Ishikawa, S.; Hara, Y.; Kamisugi, Y.; et al. SnRK2 protein kinases represent an ancient system in plants for adaptation to a terrestrial environment. Commun. Biol. 2019, 2, 30. [CrossRef]

96. Nagai, K.; Mori, Y.; Ishikawa, S.; Furuta, T.; Gamuyao, R.; Niimi, Y.; Hobo, T.; Fukuda, M.; Kojima, M.; Takebayashi, Y.; et al. Antagonistic regulation of the gibberellic acid response during stem growth in rice. Nature 2020, 584, 109-114. [CrossRef]

97. Hattori, Y.; Nagai, K.; Furukawa, S.; Song, X.J.; Kawano, R.; Sakakibara, H.; Wu, J.; Matsumoto, T.; Yoshimura, A.; Kitano, H.; et al. The ethylene response factors SNORKEL1 and SNORKEL2 allow rice to adapt to deep water. Nature 2009, 460, 1026-1030. [CrossRef]

98. He, C.; Morgan, P.; Drew, M. Transduction of an ethylene signal is required for cell death and lysis in the root cortex of maize during aerenchyma formation induced by hypoxia. Plant Physiol. 1996, 112, 463-472. [CrossRef]

99. Gibbs, D.J.; Md Isa, N.; Movahedi, M.; Lozano-Juste, J.; Mendiondo, G.M.; Berckhan, S.; Marin-de la Rosa, N.; Vicente Conde, J.; Sousa Correia, C.; Pearce, S.P.; et al. Nitric oxide sensing in plants is mediated by proteolytic control of group VII ERF transcription factors. Mol. Cell 2014, 53, 369-379. [CrossRef]

100. Reinhardt, D.; Pesce, E.-R.; Stieger, P.; Mandel, T.; Baltensperger, K.; Bennett, M.; Traas, J.; Friml, J.; Kuhlemeier, C. Regulation of phyllotaxis by polar auxin transport. Nature 2003, 426, 255-260. [CrossRef]

101. Heisler, M.G.; Ohno, C.; Das, P.; Sieber, P.; Reddy, G.V.; Long, J.A.; Meyerowitz, E.M. Patterns of auxin transport and gene expression during primordium development revealed by live imaging of the Arabidopsis inflorescence meristem. Curr. Biol. 2005, 15, 1899-1911. [CrossRef] [PubMed]

102. Zhao, Y.; Christensen, S.; Fankhauser, C.; Cashman, J.; Cohen, J.; Weigel, D.; Chory, J. A role for flavin monooxygenase-like enzymes in auxin biosynthesis. Science 2001, 291, 306-309. [CrossRef] [PubMed]

103. Phillips, K.; Skirpan, A.; Liu, X.; Masterson, A.; Slewinski, T.; Hudson, C.; Barazesh, S.; Cohen, J.; Malcomber, S.; McSteen, P. vanishing tassel2 Encodes a Grass-Specific Tryptophan Aminotransferase Required for Vegetative and Reproductive Development in Maize. Plant Cell 2011, 23, 550-566. [CrossRef] [PubMed]

104. Shwartz, I.; Levy, M.; Ori, N.; Bar, M. Hormones in tomato leaf development. Dev. Biol. 2016, 419, 132-142. [CrossRef] [PubMed]

105. Gordon, S.; Chickarmane, V.; Ohno, C.; Meyerowitz, E. Multiple feedback loops through cytokinin signaling control stem cell number within the Arabidopsis shoot meristem. Proc. Natl. Acad. Sci. USA 2009, 106, 16529-16534. [CrossRef]

106. Kurakawa, T.; Ueda, N.; Maekawa, M.; Kobayashi, K.; Kojima, M.; Nagato, Y.; Sakakibara, H.; Kyozuka, J. Direct control of shoot meristem activity by a cytokinin-activating enzyme. Nature $\mathbf{2 0 0 7}, \mathbf{4 4 5}, \mathbf{6 5 2 - 6 5 5}$. [CrossRef] 
107. Shani, E.; Ben-Gera, H.; Shleizer-Burko, S.; Burko, Y.; Weiss, D.; Ori, N. Cytokinin regulates compound leaf development in tomato. Plant Cell 2010, 22, 3206-3217. [CrossRef]

108. Fleishon, S.; Shani, E.; Ori, N.; Weiss, D. Negative reciprocal interactions between gibberellin and cytokinin in tomato. New Phytol. 2011, 190, 609-617. [CrossRef]

109. Jasinski, S.; Tattersall, A.; Piazza, P.; Hay, A.; Martinez-Garcia, J.F.; Schmitz, G.; Theres, K.; McCormick, S.; Tsiantis, M. PROCERA encodes a DELLA protein that mediates control of dissected leaf form in tomato. Plant J. 2008, 56, 603-612. [CrossRef]

110. DeMason, D.A.; Chetty, V.J. Interactions between GA, auxin, and UNI expression controlling shoot ontogeny, leaf morphogenesis, and auxin response in Pisum sativum (Fabaceae): Or how the uni-tac mutant is rescued. Am. J. Bot. 2011, 98, 775-791. [CrossRef]

111. Li, G.; Hu, S.; Yang, J.; Schultz, E.A.; Clarke, K.; Hou, H. Water-Wisteria as an ideal plant to study heterophylly in higher aquatic plants. Plant Cell Rep. 2017, 36, 1225-1236. [CrossRef] [PubMed]

112. Sack, L.; Scoffoni, C. Leaf venation: Structure, function, development, evolution, ecology and applications in the past, present and future. New Phytol. 2013, 198, 983-1000. [CrossRef] [PubMed]

113. Fanourakis, D.; Bouranis, D.; Giday, H.; Carvalho, D.R.; Rezaei Nejad, A.; Ottosen, C.O. Improving stomatal functioning at elevated growth air humidity: A review. J. Plant Physiol. 2016, 207, 51-60. [CrossRef] [PubMed]

114. Du, F.; Guan, C.; Jiao, Y. Molecular Mechanisms of Leaf Morphogenesis. Mol. Plant 2018, 11, 1117-1134. [CrossRef] [PubMed]

115. Hay, A.; Tsiantis, M. KNOX genes: Versatile regulators of plant development and diversity. Development 2010, 137, 3153-3165. [CrossRef]

116. Guo, M.; Thomas, J.; Collins, G.; Timmermans, M.C. Direct repression of KNOX loci by the ASYMMETRIC LEAVES1 complex of Arabidopsis. Plant Cell 2008, 20,48-58. [CrossRef]

117. Luo, M.; Yu, C.W.; Chen, F.F.; Zhao, L.; Tian, G.; Liu, X.; Cui, Y.; Yang, J.Y.; Wu, K. Histone deacetylase HDA6 is functionally associated with AS1 in repression of KNOX genes in arabidopsis. PLoS Genet. 2012, 8, e1003114. [CrossRef]

118. Iwakawa, H.; Takahashi, H.; Machida, Y.; Machida, C. Roles of ASYMMETRIC LEAVES2 (AS2) and nucleolar proteins in the adaxial-abaxial polarity specification at the perinucleolar region in Arabidopsis. Int. J. Mol. Sci. 2020, 21, 7314. [CrossRef]

119. Hibara, K.; Karim, M.R.; Takada, S.; Taoka, K.; Furutani, M.; Aida, M.; Tasaka, M. Arabidopsis CUP-SHAPED COTYLEDON3 regulates postembryonic shoot meristem and organ boundary formation. Plant Cell 2006, 18, 2946-2957. [CrossRef]

120. Hay, A.; Kaur, H.; Phillips, A.; Hedden, P.; Hake, S.; Tsiantis, M. The gibberellin pathway mediates KNOTTED1-Type Homeobox function in plants with different body plans. Curr. Boil. 2002, 12, 1557-1565. [CrossRef]

121. Maugarny-Cales, A.; Laufs, P. Getting leaves into shape: A molecular, cellular, environmental and evolutionary view. Development 2018, 145, dev161646. [CrossRef] [PubMed]

122. Moon, J.; Hake, S. How a leaf gets its shape. Curr. Opin. Plant Biol. 2011, 14, 24-30. [CrossRef] [PubMed]

123. Canales, C.; Barkoulas, M.; Galinha, C.; Tsiantis, M. Weeds of change: Cardamine hirsuta as a new model system for studying dissected leaf development. J. Plant Res. 2010, 123, 25-33. [CrossRef] [PubMed]

124. Eshed, Y.; Baum, S.; Perea, J.; Bowman, J. Establishment of polarity in lateral organs of plants. Curr. Boil. 2001, 11, 1251-1260. [CrossRef]

125. Eshed, Y.; Izhaki, A.; Baum, S.F.; Floyd, S.K.; Bowman, J.L. Asymmetric leaf development and blade expansion in Arabidopsis are mediated by KANADI and YABBY activities. Development 2004, 131, 2997-3006. [CrossRef]

126. Kerstetter, R.; Bollman, K.; Taylor, R.; Bomblies, K.; Poethig, R. KANADI controls organ polarity in Arabidopsis. Nature 2001, 411, 706-709. [CrossRef]

127. Emery, J.F.; Floyd, S.K.; Alvarez, J.; Eshed, Y.; Hawker, N.P.; Izhaki, A.; Baum, S.F.; Bowman, J.L. Radial patterning of Arabidopsis shoots by class III HD-ZIP and KANADI genes. Curr. Biol. 2003, 13, 1768-1774. [CrossRef]

128. Tang, G.; Reinhart, B.; Bartel, D.; Zamore, P. A biochemical framework for RNA silencing in plants. Genes Dev. 2003, 17, 49-63. [CrossRef]

129. Yao, X.; Wang, H.; Li, H.; Yuan, Z.; Li, F.; Yang, L.; Huang, H. Two types of cis-acting elements control the abaxial epidermis-specific transcription of the MIR165a and MIR166a genes. FEBS Lett. 2009, 583, 3711-3717. [CrossRef]

130. Tatematsu, K.; Toyokura, K.; Miyashima, S.; Nakajima, K.; Okada, K. A molecular mechanism that confines the activity pattern of miR165 in Arabidopsis leaf primordia. Plant J. 2015, 82, 596-608. [CrossRef]

131. Li, H.; Xu, L.; Wang, H.; Yuan, Z.; Cao, X.; Yang, Z.; Zhang, D.; Xu, Y.; Huang, H. The Putative RNA-dependent RNA polymerase RDR6 acts synergistically with ASYMMETRIC LEAVES1 and 2 to repress BREVIPEDICELLUS and MicroRNA165/166 in Arabidopsis leaf development. Plant Cell 2005, 17, 2157-2171. [CrossRef] [PubMed]

132. Fu, Y.; Xu, L.; Xu, B.; Yang, L.; Ling, Q.; Wang, H.; Huang, H. Genetic interactions between leaf polarity-controlling genes and ASYMMETRIC LEAVES1 and 2 in Arabidopsis leaf patterning. Plant Cell Physiol. 2007, 48, 724-735. [CrossRef] [PubMed]

133. Hunter, C.; Willmann, M.; Wu, G.; Yoshikawa, M.; Gutiérrez-Nava, M.; Poethig, S. Trans-acting siRNA-mediated repression of ETTIN and ARF4 regulates heteroblasty. Development 2006, 133, 2973-2981. [CrossRef] [PubMed]

134. Chitwood, D.H.; Nogueira, F.T.; Howell, M.D.; Montgomery, T.A.; Carrington, J.C.; Timmermans, M.C. Pattern formation via small RNA mobility. Genes Dev. 2009, 23, 549-554. [CrossRef] [PubMed]

135. Marin, E.; Jouannet, V.; Herz, A.; Lokerse, A.S.; Weijers, D.; Vaucheret, H.; Nussaume, L.; Crespi, M.D.; Maizel, A. miR390, Arabidopsis TAS3 tasiRNAs, and their AUXIN RESPONSE FACTOR targets define an autoregulatory network quantitatively regulating lateral root growth. Plant Cell 2010, 22, 1104-1117. [CrossRef] [PubMed]

136. Nikovics, K.; Blein, T.; Peaucelle, A.; Ishida, T.; Morin, H.; Aida, M.; Laufs, P. The balance between the MIR164A and CUC2 genes controls leaf margin serration in Arabidopsis. Plant Cell 2006, 18, 2929-2945. [CrossRef] 
137. Balkunde, R.; Kitagawa, M.; Xu, X.M.; Wang, J.; Jackson, D. SHOOT MERISTEMLESS trafficking controls axillary meristem formation, meristem size and organ boundaries in Arabidopsis. Plant J. 2017, 90, 435-446. [CrossRef]

138. Norberg, M.; Holmlund, M.; Nilsson, O. The BLADE ON PETIOLE genes act redundantly to control the growth and development of lateral organs. Development 2005, 132, 2203-2213. [CrossRef]

139. Jun, J.H.; Ha, C.M.; Fletcher, J.C. BLADE-ON-PETIOLE1 coordinates organ determinacy and axial polarity in arabidopsis by directly activating ASYMMETRIC LEAVES2. Plant Cell 2010, 22, 62-76. [CrossRef]

140. Chung, Y.; Zhu, Y.; Wu, M.F.; Simonini, S.; Kuhn, A.; Armenta-Medina, A.; Jin, R.; Ostergaard, L.; Gillmor, C.S.; Wagner, D. Auxin Response Factors promote organogenesis by chromatin-mediated repression of the pluripotency gene SHOOTMERISTEMLESS. Nat. Commun. 2019, 10, 886. [CrossRef]

141. Qi, J.; Wang, Y.; Yu, T.; Cunha, A.; Wu, B.; Vernoux, T.; Meyerowitz, E.; Jiao, Y. Auxin depletion from leaf primordia contributes to organ patterning. Proc. Natl. Acad. Sci. USA 2014, 111, 18769-18774. [CrossRef] [PubMed]

142. Guan, C.; Wu, B.; Yu, T.; Wang, Q.; Krogan, N.T.; Liu, X.; Jiao, Y. Spatial auxin signaling controls leaf flattening in Arabidopsis. Curr. Biol. 2017, 27, 2940-2950.e2944. [CrossRef] [PubMed]

143. Bai, Y.; Falk, S.; Schnittger, A.; Jakoby, M.J.; Hulskamp, M. Tissue layer specific regulation of leaf length and width in Arabidopsis as revealed by the cell autonomous action of ANGUSTIFOLIA. Plant J. 2010, 61, 191-199. [CrossRef] [PubMed]

144. Tadege, M.; Lin, H.; Bedair, M.; Berbel, A.; Wen, J.; Rojas, C.M.; Niu, L.; Tang, Y.; Sumner, L.; Ratet, P.; et al. STENOFOLIA regulates blade outgrowth and leaf vascular patterning in Medicago truncatula and Nicotiana sylvestris. Plant Cell 2011, 23, 2125-2142. [CrossRef] [PubMed]

145. Nakata, M.; Matsumoto, N.; Tsugeki, R.; Rikirsch, E.; Laux, T.; Okada, K. Roles of the middle domain-specific WUSCHELRELATED HOMEOBOX genes in early development of leaves in Arabidopsis. Plant Cell 2012, 24, 519-535. [CrossRef] [PubMed]

146. Ori, N.; Cohen, A.R.; Etzioni, A.; Brand, A.; Yanai, O.; Shleizer, S.; Menda, N.; Amsellem, Z.; Efroni, I.; Pekker, I.; et al. Regulation of LANCEOLATE by miR319 is required for compound-leaf development in tomato. Nat. Genet. 2007, 39, 787-791. [CrossRef]

147. Kim, J.H.; Choi, D.; Kende, H. The AtGRF family of putative transcription factors is involved in leaf and cotyledon growth in Arabidopsis. Plant J. 2003, 36, 94-104. [CrossRef] [PubMed]

148. Rodriguez, R.E.; Mecchia, M.A.; Debernardi, J.M.; Schommer, C.; Weigel, D.; Palatnik, J.F. Control of cell proliferation in Arabidopsis thaliana by microRNA miR396. Development 2010, 137, 103-112. [CrossRef]

149. Debernardi, J.M.; Mecchia, M.A.; Vercruyssen, L.; Smaczniak, C.; Kaufmann, K.; Inze, D.; Rodriguez, R.E.; Palatnik, J.F. Posttranscriptional control of GRF transcription factors by microRNA miR396 and GIF co-activator affects leaf size and longevity. Plant J. 2014, 79, 413-426. [CrossRef]

150. Rodriguez, R.E.; Debernardi, J.M.; Palatnik, J.F. Morphogenesis of simple leaves: Regulation of leaf size and shape. Wiley Interdiscip. Rev. Dev. Biol. 2014, 3, 41-57. [CrossRef]

151. Schommer, C.; Debernardi, J.M.; Bresso, E.G.; Rodriguez, R.E.; Palatnik, J.F. Repression of cell proliferation by miR319-regulated TCP4. Mol. Plant 2014, 7, 1533-1544. [CrossRef] [PubMed]

152. Blein, T.; Pulido, A.; Vialette-Guiraud, A.; Nikovics, K.; Morin, H.; Hay, A.; Johansen, I.E.; Tsiantis, M.; Laufs, P. A conserved molecular framework for compound leaf development. Science 2008, 322, 1835-1839. [CrossRef] [PubMed]

153. Koyama, T.; Mitsuda, N.; Seki, M.; Shinozaki, K.; Ohme-Takagi, M. TCP transcription factors regulate the activities of ASYMMETRIC LEAVES1 and miR164, as well as the auxin response, during differentiation of leaves in Arabidopsis. Plant Cell 2010, 22, 3574-3588. [CrossRef] [PubMed]

154. Sha, S.; Chen, D.; Liu, M.; Li, K.L.; Jiang, C.K.; Wang, D.H.; Guo, Y.P. To be serrate or pinnate: Diverse leaf forms of yarrows (Achillea) are linked to differential expression patterns of NAM genes. Ann. Bot. 2018, 121, 255-266. [CrossRef] [PubMed]

155. Alvarez, J.P.; Furumizu, C.; Efroni, I.; Eshed, Y.; Bowman, J.L. Active suppression of a leaf meristem orchestrates determinate leaf growth. Elife 2016, 5, e15023. [CrossRef]

156. Wang, H.; Niu, H.; Li, C.; Shen, G.; Liu, X.; Weng, Y.; Wu, T.; Li, Z. WUSCHEL-related homeobox1 (WOX1) regulates vein patterning and leaf size in Cucumis sativus. Hortic. Res. 2020, 7, 182. [CrossRef]

157. Wang, H.; Chen, J.; Wen, J.; Tadege, M.; Li, G.; Liu, Y.; Mysore, K.S.; Ratet, P.; Chen, R. Control of compound leaf development by FLORICAULA/LEAFY ortholog SINGLE LEAFLET1 in Medicago truncatula. Plant Physiol. 2008, 146, 1759-1772. [CrossRef]

158. Byrne, M.E. Making leaves. Curr. Opin. Plant Biol. 2012, 15, 24-30. [CrossRef]

159. Blein, T.; Hasson, A.; Laufs, P. Leaf development: What it needs to be complex. Curr. Opin. Plant Biol. 2010, 13, 75-82. [CrossRef]

160. Niinemets, U.; Portsmuth, A.; Tena, D.; Tobias, M.; Matesanz, S.; Valladares, F. Do we underestimate the importance of leaf size in plant economics? Disproportional scaling of support costs within the spectrum of leaf physiognomy. Ann. Bot. 2007, 100, 283-303. [CrossRef]

161. Sicard, A.; Thamm, A.; Marona, C.; Lee, Y.W.; Wahl, V.; Stinchcombe, J.R.; Wright, S.I.; Kappel, C.; Lenhard, M. Repeated evolutionary changes of leaf morphology caused by mutations to a homeobox gene. Curr. Biol. 2014, 24, 1880-1886. [CrossRef] [PubMed]

162. Vlad, D.; Kierzkowski, D.; Rast-Somssich, M.; Vuolo, F.; Ioio, R.; Galinha, C.; Gan, X.; Hajheidari, M.; Hay, A.; Smith, R.; et al. Leaf shape evolution through duplication, regulatory diversification, and loss of a homeobox gene. Science 2014, 343, 780-783. [CrossRef] [PubMed]

163. Kierzkowski, D.; Runions, A.; Vuolo, F.; Strauss, S.; Lymbouridou, R.; Routier-Kierzkowska, A.L.; Wilson-Sanchez, D.; Jenke, H.; Galinha, C.; Mosca, G.; et al. A growth-based framework for leaf shape development and diversity. Cell 2019, 177, 1405-1418.e1417. [CrossRef] [PubMed] 
164. Hajheidari, M.; Wang, Y.; Bhatia, N.; Vuolo, F.; Franco-Zorrilla, J.M.; Karady, M.; Mentink, R.A.; Wu, A.; Oluwatobi, B.R.; Muller, B.; et al. Autoregulation of RCO by low-affinity binding modulates cytokinin action and shapes leaf diversity. Curr. Biol. 2019, 29, 4183-4192. [CrossRef] [PubMed]

165. Hudson, A. Evolution: How a homeobox gene cuts the mustard leaf. Curr. Biol. 2019, 29, R1305-R1307. [CrossRef] [PubMed]

166. Nakayama, H.; Sakamoto, T.; Okegawa, Y.; Kaminoyama, K.; Fujie, M.; Ichihashi, Y.; Kurata, T.; Motohashi, K.; Al-Shehbaz, I.; Sinha, N.; et al. Comparative transcriptomics with self-organizing map reveals cryptic photosynthetic differences between two accessions of North American Lake cress. Sci. Rep. 2018, 8, 3302. [CrossRef]

167. Sadiq, Y.; Zaid, A.; Khan, M.M.A. Adaptive physiological responses of plants under abiotic stresses: Role of phytohormones. In Plant Ecophysiology and Adaptation under Climate Change: Mechanisms and Perspectives I: General Consequences and Plant Responses; Hasanuzzaman, M., Ed.; Springer: Singapore, 2020; pp. 797-824. [CrossRef]

168. Bhatt, D.; Nath, M.; Sharma, M.; Bhatt, M.; Bisht, D.; Butani, N. Role of growth regulators and phytohormones in overcoming environmental stress. In Protective Chemical Agents in the Amelioration of Plant Abiotic Stress; Wiley-Blackwell: Hoboken, NJ, USA, 2020; pp. 254-279. [CrossRef]

169. Khan, N.; Bano, A.; Ali, S.; Babar, M.A. Crosstalk amongst phytohormones from planta and PGPR under biotic and abiotic stresses. Plant Growth Regul. 2020, 90, 189-203. [CrossRef]

170. Zhang, R.; Fu, X.; Zhao, C.; Cheng, J.; Liao, H.; Wang, P.; Yao, X.; Duan, X.; Yuan, Y.; Xu, G.; et al. Identification of the key regulatory genes involved in elaborate petal development and specialized character formation in Nigella damascena (Ranunculaceae). Plant Cell 2020, 32, 3095-3112. [CrossRef]

171. Tylewicz, S.; Petterle, A.; Marttila, S.; Miskolczi, P.; Azeez, A.; Singh, R.; Immanen, J.; Mähler, N.; Hvidsten, T.; Eklund, D.M.; et al. Photoperiodic control of seasonal growth is mediated by ABA acting on cell-cell communication. Science 2018, 360, eaan8576. [CrossRef]

172. Kim, S.; Hwang, G.; Kim, S.; Thi, T.N.; Kim, H.; Jeong, J.; Kim, J.; Kim, J.; Choi, G.; Oh, E. The epidermis coordinates thermoresponsive growth through the phyB-PIF4-auxin pathway. Nat. Commun. 2020, 11, 1053. [CrossRef]

173. Zhao, Y.; Antoniou-Kourounioti, R.L.; Calder, G.; Dean, C.; Howard, M. Temperature-dependent growth contributes to long-term cold sensing. Nature 2020, 583, 825-829. [CrossRef] [PubMed]

174. Zandalinas, S.I.; Fichman, Y.; Devireddy, A.R.; Sengupta, S.; Azad, R.K.; Mittler, R. Systemic signaling during abiotic stress combination in plants. Proc. Natl. Acad. Sci. USA 2020, 117, 13810-13820. [CrossRef] [PubMed]

175. Yang, Y.; Zhang, Q.; Huang, G.; Peng, S.; Li, Y. Temperature responses of photosynthesis and leaf hydraulic conductance in rice and wheat. Plant Cell Environ. 2020, 43, 1437-1451. [CrossRef] [PubMed]

176. Sarvepalli, K.; Das Gupta, M.; Challa, K.R.; Nath, U. Molecular cartography of leaf development-Role of transcription factors. Curr. Opin. Plant Biol. 2019, 47, 22-31. [CrossRef] [PubMed] 